\title{
Studies on the South Indian Compositae \\ III. Karyomorphology of nine species of Blumea DC.
}

\author{
Abraham Mathew and P. M. Mathew \\ Department of Botany, University of Kerala, Trivandrum, India
}

Received May 23, 1980

The study of morphology of chromosomes has gained a new sphere of usefulness in dealing with the systematic relationships, phylogeny and evolution of related plant groups, in addition to providing helpful clues as to the possible modes of karyotype variation within and between species. Although South India hosts a number of genera and species of the Compositae, our present knowledge on their karyomorphology is too fragmentary and isolated. During the cytological investigation on the family recently undertaken in this Department, chromosome studies were made in about 120 species belonging to 60 genera from South India. This includes detailed karyotype studies in a few genera. Preliminary chromosome reports on two genera have been made earlier (Mathew and Mathew 1975, 1976). This paper deals with the karyomorphology of nine species of Blumea (Inuleae), and the data briefly considered in relation to chromosome evolution in the genus.

\section{Materials and methods}

Species of the genus were collected from various low and high altitude localities in South India such as Kottayam, Trivandrum, Quilon, Ernakulam, Alwaye, Ranni, Munnar and Santhenpara. As far as possible materials of each of the taxa were studied from different localities. Somatic chromosomes were studied from root tip cells. Root tip cells were collected and pretreated with a $0.002 \mathrm{M}$ solution of 8-hydroxyquinoline at $4^{\circ} \mathrm{C}$ for $2 \mathrm{hrs}$. They were then fixed in 3:1 Carnoy's fluid. For staining the chromosomes, haematoxylin was used throughout (Henderson and Lu 1968). Karyotype data were taken based on average measurements of chromosomes of 8-10 well-spread metaphase plates. Length of long arms (L) and short arms (S) were measured, and the arm ratios, relative chromosome length of different chromosomes, total complement length and size ratio (Longest-Shortest chromosome) were calculated. Classification of chromosomes in relation to their centromeric position was made according to the scheme proposed by Leven et al. (1964), and categorisation of karyotype asymmetry was made according to that of Stebbins (1958).

\section{Observations}

\section{Blumea barbata DC.}

Root tip cells showed 16 chromosomes at metaphase. They ranged in length 
Table 1. Details of karyotypes of nine species of Blumea

\begin{tabular}{|c|c|c|c|c|c|c|}
\hline \multirow{2}{*}{ Chromosome } & \multicolumn{3}{|c|}{ Chromosome length in $\mu$} & \multirow{2}{*}{ RCL } & \multirow{2}{*}{$\mathbf{r}$} & \multirow{2}{*}{$\begin{array}{c}\text { Centromere } \\
\text { position }\end{array}$} \\
\hline & Long arm & Short arm & Total & & & \\
\hline \multicolumn{7}{|l|}{ Blumea barbata } \\
\hline 1 & 4.47 & 1.90 & 6.37 & 18.90 & 2.35 & $\mathrm{sm}$ \\
\hline 2 & 4.00 & 1.80 & 5.80 & 17.21 & 2.22 & $\mathrm{sm}$ \\
\hline 3 & 2.90 & 1.83 & 4.73 & 14.03 & 1.58 & $\mathrm{~m}$ \\
\hline 4 & 2.58 & 1.30 & 3.88 & 11.51 & 1.98 & $\mathrm{sm}$ \\
\hline 5 & 1.82 & 1.75 & 3.57 & 10.59 & 1.04 & $\mathrm{~m}$ \\
\hline 6 & 2.08 & 1.15 & 3.23 & 9.58 & 1.81 & $\mathrm{sm}$ \\
\hline 7 & 2.05 & 1.03 & 3.08 & 9.14 & 1.99 & $\mathrm{sm}$ \\
\hline 8 & 2.13 & 0.92 & 3.05 & 9.05 & 2.32 & $\mathrm{sm}$ \\
\hline \multicolumn{7}{|l|}{ B. fistulosa } \\
\hline 1 & $3.86+2.14$ & 2.66 & 8.66 & 21.89 & 2.26 & $\mathbf{s m}$ \\
\hline 2 & $2.66+2.66$ & 2.00 & 7.32 & 18.50 & 2.66 & $\mathrm{sm}$ \\
\hline 3 & 2.00 & 2.00 & 4.00 & 10.11 & 1.00 & $\mathbf{M}$ \\
\hline 4 & 2.00 & 1.54 & 3.54 & 8.95 & 1.30 & $\mathrm{~m}$ \\
\hline 5 & 2.00 & 1.46 & 3.46 & 8.75 & 1.37 & $\mathrm{~m}$ \\
\hline 6 & 1.86 & 1.46 & 3.32 & 8.39 & 1.27 & $m$ \\
\hline 7 & $1.06+1.34$ & 0.87 & 3.27 & 8.24 & 2.79 & $\mathrm{sm}$ \\
\hline 8 & 1.66 & 1.46 & 3.12 & 7.89 & 1.14 & $\mathrm{~m}$ \\
\hline 9 & 1.54 & 1.34 & 2.88 & 7.28 & 1.15 & $\mathrm{~m}$ \\
\hline \multicolumn{7}{|l|}{ B. jacquemontii } \\
\hline 1 & 4.80 & 2.00 & 6.80 & 21.92 & 2.40 & $\mathrm{sm}$ \\
\hline 2 & $1.88+2.32$ & 1.56 & 5.76 & 18.63 & 2.69 & $\mathrm{sm}$ \\
\hline 3 & 1.80 & 1.24 & 3.04 & 9.83 & 1.45 & $\mathrm{~m}$ \\
\hline 4 & 1.67 & 1.44 & 3.14 & 9.83 & 1.11 & $\mathrm{~m}$ \\
\hline 5 & 1.76 & 1.08 & 2.84 & 9.18 & 1.63 & $\mathrm{~m}$ \\
\hline 6 & 1.44 & 1.04 & 2.48 & 8.03 & 1.38 & $\mathrm{~m}$ \\
\hline 7 & 1.44 & 0.96 & 2.40 & 7.76 & 1.50 & $\mathrm{~m}$ \\
\hline 8 & 1.44 & 0.92 & 2.36 & 7.63 & 1.56 & $\mathrm{~m}$ \\
\hline 9 & 1.24 & 0.96 & 2.20 & 7.12 & 1.29 & $\mathrm{~m}$ \\
\hline \multicolumn{7}{|c|}{ B. lacera var. glandulosa } \\
\hline 1 & 5.07 & 1.57 & 6.64 & 10.95 & 3.23 & st \\
\hline 2 & 4.23 & 1.70 & 5.93 & 9.78 & 2.49 & $\operatorname{sm}$ \\
\hline 3 & $2.78+1.83$ & 1.21 & 5.82 & 9.60 & 3.84 & st \\
\hline 4 & 3.83 & 1.50 & 5.33 & 8.79 & 2.55 & $\operatorname{sm}$ \\
\hline 5 & 1.90 & 1.42 & 3.32 & 5.47 & 1.34 & $\mathrm{~m}$ \\
\hline 6 & 1.67 & 1.57 & 3.23 & 5.33 & 1.08 & $\mathrm{~m}$ \\
\hline 7 & 1.58 & 1.47 & 3.05 & 5.03 & 1.07 & $\mathrm{~m}$ \\
\hline 8 & 1.57 & 1.27 & 2.84 & 4.68 & 1.24 & $\mathrm{~m}$ \\
\hline 9 & 1.58 & 1.25 & 2.83 & 4.67 & 1.26 & $\mathrm{~m}$ \\
\hline 10 & 1.67 & 1.00 & 2.67 & 4.40 & 1.67 & $\mathrm{~m}$ \\
\hline 11 & 1.33 & 1.28 & 2.62 & 4.32 & 1.04 & $\mathrm{~m}$ \\
\hline 12 & 1.63 & 0.93 & 2.56 & 4.24 & 1.75 & $\mathrm{sm}$ \\
\hline 13 & 1.68 & 0.83 & 2.51 & 4.12 & 2.01 & $\mathrm{sm}$ \\
\hline 13 & 1.30 & 1.15 & 2.45 & 4.04 & 1.13 & $\mathrm{~m}$ \\
\hline 15 & 1.30 & 1.08 & 2.38 & 3.92 & 1.20 & $\mathrm{~m}$ \\
\hline 16 & 1.37 & 0.97 & 2.30 & 3.79 & 1.41 & $\mathrm{~m}$ \\
\hline 17 & 1.32 & 0.80 & 2.10 & 3.46 & 1.65 & $\mathrm{~m}$ \\
\hline $\begin{array}{l}18 \\
\text { B. malcolmii }\end{array}$ & 1.08 & 1.00 & 2.08 & 3.43 & 1.08 & $\mathrm{~m}$ \\
\hline
\end{tabular}




\begin{tabular}{|c|c|c|c|c|c|c|}
\hline \multirow{2}{*}{ Chromosome } & \multicolumn{3}{|c|}{ Chromosome length in $\mu$} & \multirow{2}{*}{$\mathrm{RCL}$} & \multirow{2}{*}{$r$} & \multirow{2}{*}{$\begin{array}{l}\text { Centromere } \\
\text { position }\end{array}$} \\
\hline & Long arm & Short arm & Total & & & \\
\hline 1 & 5.83 & 3.09 & 8.92 & 18.02 & 1.89 & $\mathrm{sm}$ \\
\hline 2 & 5.33 & 2.40 & 7.73 & 15.62 & 2.22 & $\mathrm{sm}$ \\
\hline 3 & 4.17 & 2.90 & 7.07 & 14.28 & 1.44 & $\mathrm{~m}$ \\
\hline 4 & 3.67 & $1.43+0.67$ & 5.77 & 11.66 & 1.78 & sm sat \\
\hline 5 & 2.88 & 2.67 & 5.55 & 11.21 & 1.08 & $\mathrm{~m}$ \\
\hline 6 & 3.23 & 1.95 & 5.18 & 10.46 & 1.67 & $\mathrm{~m}$ \\
\hline 7 & 3.33 & 1.40 & 4.73 & 9.56 & 2.38 & $\mathrm{sm}$ \\
\hline 8 & 2.92 & 1.63 & 4.55 & 9.19 & 1.79 & $\mathrm{sm}$ \\
\hline \multicolumn{7}{|c|}{ B. membranacea var. gardneri } \\
\hline 1 & 2.75 & 1.61 & 4.36 & 13.27 & 1.71 & $\mathrm{sm}$ \\
\hline 2 & 2.25 & 2.00 & 4.25 & 12.97 & 1.13 & $\mathrm{~m}$ \\
\hline 3 & 2.30 & 1.75 & 4.05 & 12.35 & 1.31 & $\mathrm{~m}$ \\
\hline 4 & 2.00 & 1.85 & 3.85 & 11.71 & 1.08 & $\mathrm{~m}$ \\
\hline 5 & 1.80 & 1.75 & 3.55 & 10.84 & 1.03 & $\mathrm{~m}$ \\
\hline 6 & 2.00 & 1.40 & 3.40 & 10.34 & 1.34 & $\mathrm{~m}$ \\
\hline 7 & 1.70 & 1.50 & 3.20 & 9.74 & 1.13 & $\mathrm{~m}$ \\
\hline 8 & 1.61 & 1.50 & 3.11 & 9.47 & 1.07 & $\mathrm{~m}$ \\
\hline 9 & 1.75 & 1.31 & 3.06 & 9.33 & 1.34 & $\mathrm{~m}$ \\
\hline \multicolumn{7}{|l|}{ B. oxyodonta } \\
\hline 1 & $4.00+2.67$ & 2.33 & 9.00 & 22.22 & 2.86 & $\mathrm{sm}$ \\
\hline 2 & 4.70 & 2.13 & 6.93 & 16.86 & 2.21 & $\mathrm{sm}$ \\
\hline 3 & 2.43 & 1.90 & 4.33 & 10.69 & 1.28 & $\mathrm{~m}$ \\
\hline 4 & 2.83 & 1.30 & 4.13 & 10.19 & 2.18 & $\mathrm{sm}$ \\
\hline 5 & 2.37 & 1.43 & 3.80 & 9.38 & 1.67 & $\mathrm{~m}$ \\
\hline 6 & 1.87 & 1.77 & 3.64 & 8.99 & 1.06 & $\mathrm{~m}$ \\
\hline 7 & 2.00 & 1.50 & 3.50 & 8.64 & 1.33 & $\mathrm{~m}$ \\
\hline 8 & 1.70 & 1.63 & 3.33 & 8.22 & 1.04 & $\mathrm{~m}$ \\
\hline 9 & 1.67 & 1.23 & 2.94 & 7.26 & 1.36 & $\mathrm{~m}$ \\
\hline \multicolumn{7}{|l|}{ B. virens } \\
\hline 1 & 3.08 & 1.58 & 4.66 & 14.93 & 1.97 & $\mathrm{sm}$ \\
\hline 2 & 2.68 & 1.43 & 4.11 & 13.17 & 1.87 & $\mathrm{sm}$ \\
\hline 3 & 1.93 & 1.83 & 3.76 & 12.05 & 1.05 & $\mathrm{~m}$ \\
\hline 4 & 2.52 & 0.88 & 3.40 & 10.89 & 2.85 & $\mathrm{sm}$ \\
\hline 5 & 2.05 & 1.33 & 3.38 & 10.83 & 1.54 & $\mathrm{~m}$ \\
\hline 6 & 1.90 & 1.28 & 3.18 & 10.19 & 1.48 & $\mathrm{~m}$ \\
\hline 7 & 2.13 & 0.92 & 3.05 & 9.77 & 2.33 & $\mathrm{sm}$ \\
\hline 8 & 2.12 & 0.90 & 3.02 & 9.36 & 2.24 & $\mathrm{sm}$ \\
\hline 9 & 1.57 & 1.18 & 2.75 & 8.81 & 1.32 & $\mathrm{~m}$ \\
\hline \multicolumn{7}{|l|}{ B. wightiana } \\
\hline 1 & 3.70 & 1.40 & 5.10 & 22.06 & 2.64 & $\mathrm{sm}$ \\
\hline 2 & 3.07 & 1.10 & 4.17 & 18.04 & 2.79 & $\mathrm{sm}$ \\
\hline 3 & 1.30 & 1.07 & 2.37 & 10.68 & 1.11 & $\mathrm{~m}$ \\
\hline 4 & 1.10 & 1.07 & 2.17 & 9.39 & 1.02 & $\mathrm{~m}$ \\
\hline 5 & 1.33 & 0.77 & 2.10 & 9.08 & 1.73 & $\mathrm{sm}$ \\
\hline 6 & 1.03 & 0.93 & 1.96 & 8.52 & 1.11 & $\mathrm{~m}$ \\
\hline 7 & 0.97 & 0.95 & 1.92 & 8.30 & 1.02 & $\mathrm{~m}$ \\
\hline 8 & 1.00 & 0.72 & 1.72 & 7.48 & 1.37 & $\mathrm{~m}$ \\
\hline 9 & 0.83 & 0.68 & 1.51 & 6.57 & 1.22 & $\mathrm{~m}$ \\
\hline
\end{tabular}



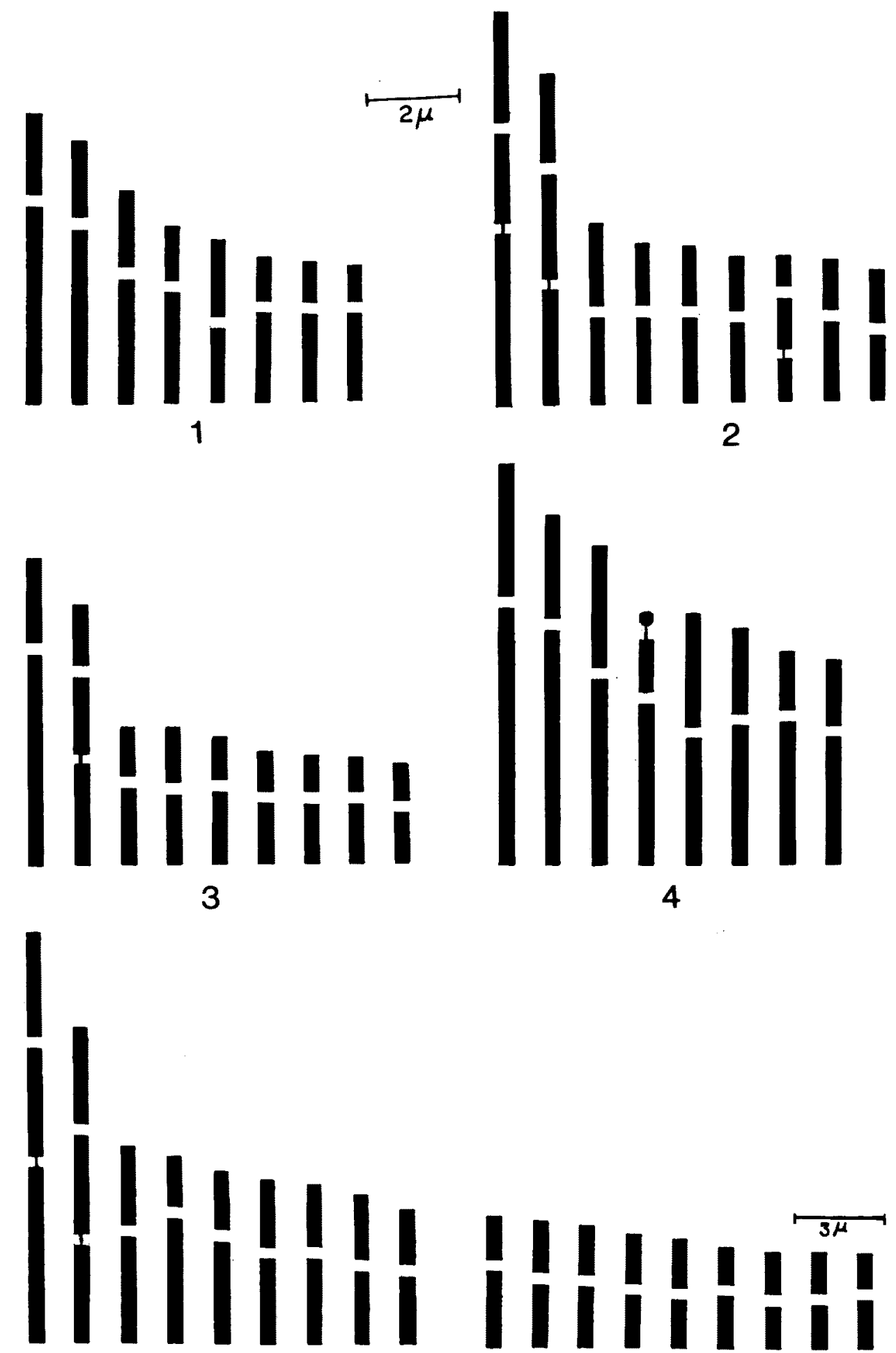

5

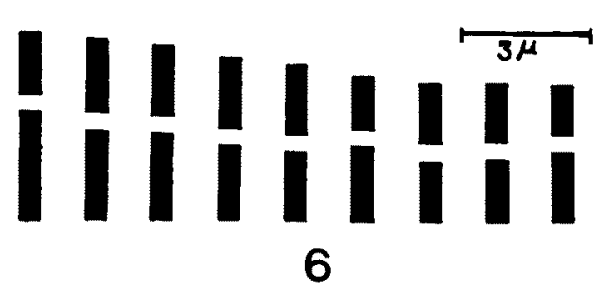


from 3.05-6.37 $\mu$, and consisted of 2 m-type and 6 sm-type pairs of chromosomes (Table 1 and Fig. 1). The karyotype belonged to the $2 \mathrm{~B}$ category.

\section{B. fistulosa (Roxb.) Kurz. (=B. glomerata)}

Eighteen chromosomes were observed in the root tip cells at metaphase which ranged in length from $2.88-8.66 \mu$. Two pairs were distinctly larger than the rest. The karyotype consisted of $1 \mathrm{M}$-type, $5 \mathrm{~m}$-type and $3 \mathrm{sm}$-type pairs of chromosomes, and it belonged to the 2B category (Table 1 and Fig. 2). The 1st, 2nd and 7th pairs of chromosomes possessed secondary constrictions on their long arms.
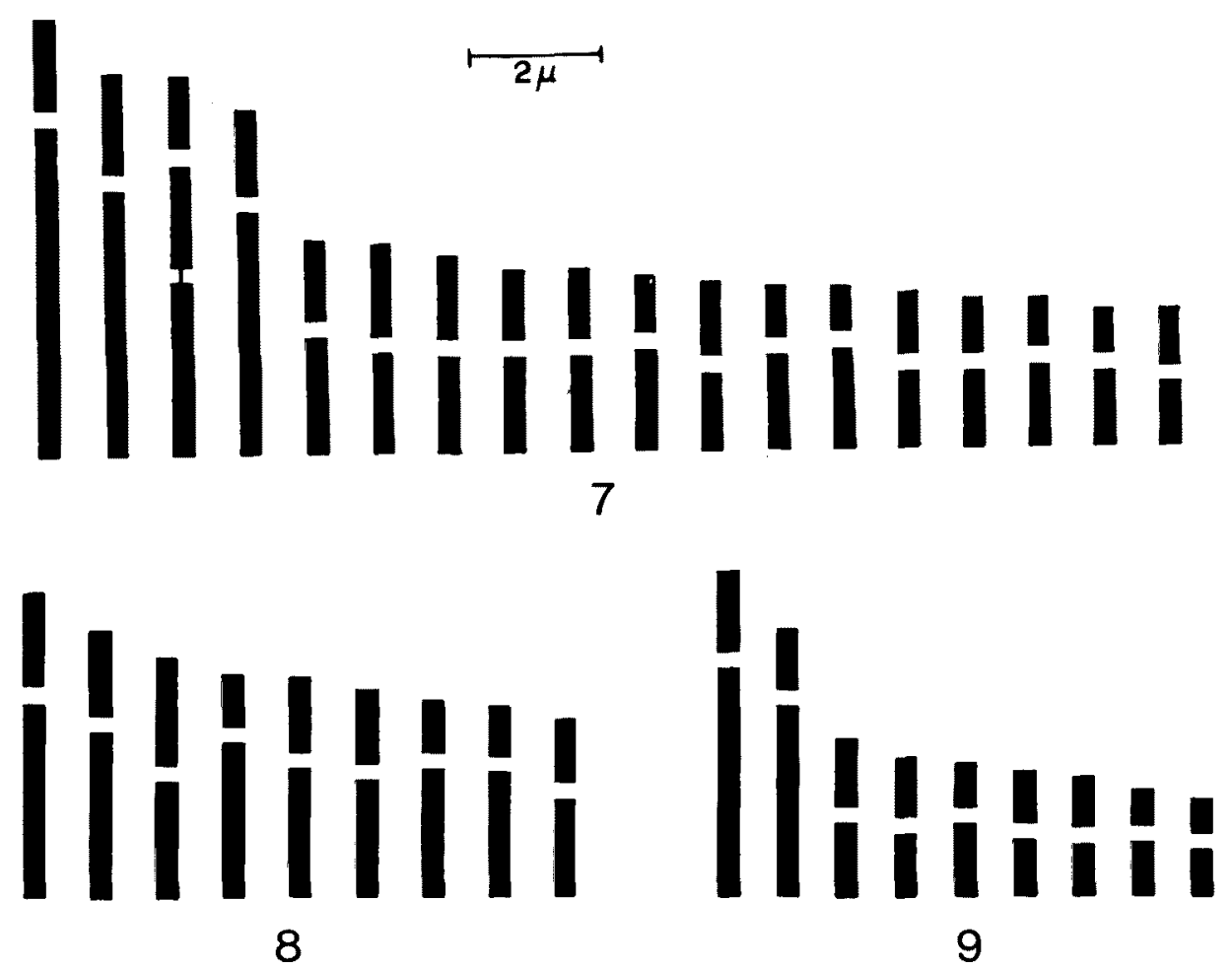

Figs. 7-9. Idiograms of three species of Blumea. 7, Blumea lacera var. glandulosa, $\mathbf{n}=18 . \quad 8$, B. virens, $\mathrm{n}=9 . \quad 9$, B. wightiana, $\mathrm{n}=9$.

B. jacquemontii Hook $\mathrm{f}$.

Root tip cells of this species showed 18 chromosomes at metaphase which ranged in length from 2.2-6.8 $\mu$. Here also two pairs were larger in size. Chromosome No. 2 possessed a secondary constriction on the long arm. The karyotype consisted of 7 pairs of m-type and 2 of sm-type chromosomes, and it belonged to the 2B category (Table 1 and Fig. 3 ).

Figs. 1-6. Idiograms of six species of Blumea. 1, Blumea barbata, $\mathrm{n}=8.2$, B. fistulosa, $\mathrm{n}=9$. 3, B. jacquemontii, $\mathrm{n}=9.4, B$. malcolme $i, \mathrm{n}=8 . \quad 5, B$. oxyodonta, $\mathrm{n}=9.6, B$. membranacea var. gardneri, $\mathrm{n}=9$. 


\section{B. lacera DC. var. glandulosa}

Thirtysix chromosomes were observed in the root tip cells at metaphase. They ranged in length from 2.08-6.64 $\mu$. The karyotype consisted of 12 pairs of m-type, 4 of sm-type and 2 of st-type chromosomes (Table 1 and Fig. 7). The third pair of chromosomes showed a secondary constriction on the long arm. Here also the somatic complement exhibited recognisable bimodality, in which four pairs were large sized and the rest distinctly smaller. The karyotype belonged to the $2 \mathrm{~B}$ category.

Miyagi (1971) reported $2 \mathrm{n}=18$ for $B$. lacera and the present cytotype is a new report for this taxon.

\section{B. malcomei Hook f.}

At metaphase the root tip cells showed 16 chromosomes which ranged in length from $4.55-8.92 \mu$. The chromosomes were recognizably larger than the other diploid species and it possessed a total chromosome size of $99 \mu$. Chromosome No. 4 possessed a globular satellite on the short arm. The karyotype consisted of 3 pairs of m-type and 5 of sm-type chromosomes (Table 1 and Fig. 4), and it belonged to the $2 \mathrm{~A}$ category.

\section{B. membranacea DC. var. gardneri}

Root tip cells showed 18 chromosomes at metaphase, ranging in length from 3.06-4.36 $\mu$. The chromosomes were much smaller in size than the other diploid species. The karyotype is of the 1A category, and consisted of 8 pairs of m-type and 1 of sm-type chromosomes (Table 1 and Fig. 6).

\section{B. oxyodonta DC.}

Root tip cells of this species showed 18 chromosomes at metaphase, ranging in length from 2.94-9.0 $\mu$. Two pairs were distinctly larger in size, and both of them possessed secondary constrictions on the long arms. The karyotype consisted of 6 pairs of m-type and 3 of șm-type chromosomes (Table 1 and Fig. 5) and belonged to the $2 \mathrm{~B}$ category.

B. virens $\mathrm{DC}$.

Eighteen chromosomes were observed in the root tip cells at metaphase which ranged in size from $2.75-4.66 \mu$. The karyotype belonged to the $2 \mathrm{~A}$ category, and it consisted of 4 pairs of m-type and 5 of sm-type chromosomes (Table 1 and Fig. 8).

B. wightiana DC.

Root tip cells showed 18 chromosomes at metaphase, and they ranged in size from 1.51-5.1 $\mu$. The somatic chromosomes apparently fall under two size classes, two pair being distinctly larger in size. The karyotype consisted of 6 pairs of m-type and 3 of sm-type chromosomes (Table 1 and Fig. 9), and it belonged to the 2B category.

\section{Discussion}

Chromosome data on Blumea show that the genus is multibasic $(x=8,9,10,11)$. 
Bulk of the South Indian species examined by us and also those reported by others from this region (Chennaveeraiah and Patil 1972) are based on $x=9$, with only two species reported here, namely $B$. barbata and $B$. malcolmei showing $x=8$. The other two basic numbers ( $\mathrm{x}=10$ and 11) are common among the North Indian taxa (Mehra et al. 1965, Gupta 1969). In an earlier report we had suggested (Mathew and Mathew 1975) that in Blumea $\mathrm{x}=10$ could be the earlier evolved condition from which the other constitutions evolved by incidence of aneuploidy in either direction. It was also postulated that the $\mathrm{x}=10$ condition could be of polyploid origin from ancestral taxa with $\mathrm{n}=5$.

Karyomorphology of species reported here show that karyotypes of both the $\mathrm{x}=9$ and $\mathrm{x}=8$ species of Blumea are moderately asymmetrical ( $2 \mathrm{~A}$ and $2 \mathrm{~B}$ ), and it appears that the pattern of karyotype variation among the South Indian group of species of this genus is one of decreasing basic number unassociated with change in karyotype asymmetry. However, in finer details of chromosome morphology, the karyotypes of the $\mathrm{x}=9$ species in general are more asymmetrical. Morphological changes of chromosomes involving shift of centromere position in the $x=9$ group have occurred mainly in five chromosomes (Fig. 10), such as chromosomes 1, 2, 4,

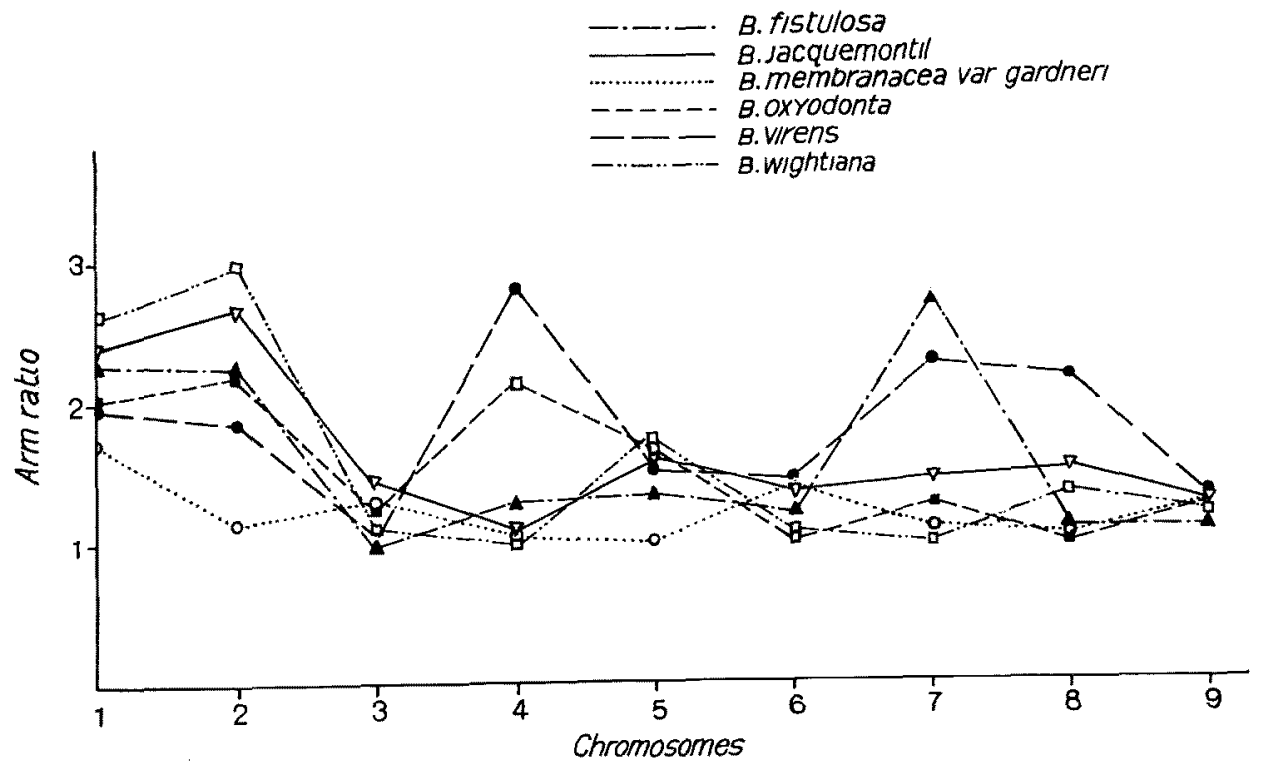

Fig. 10. Arm ratios in six $\mathrm{x}=9$ species of Blumea.

7 and 8 , while shift of centromeric position of a comparable magnitude does not seem to have occurred in the $x=8$ species (Fig. 11). The fact that species with the derived $x=8$ constitution to possess less specialised karyotypes as compared to those of their $x=9$ progenitors apparently presents a strange situation. A possible explanation for this is that the karyotypes of the South Indian species of Blumea could have been relatively less asymmetrical and unspecialised before the numerical change from $x=9$ to $x=8$ had occurred, and that since the numerical change, the structural changes in chromosomes leading to karyotype asymmetry must have 
been more active in the $x=9$ group.

The chromosome measurements of the $x=9$ species show that many of them exhibit appreciable intrakaryotypic size difference. In four of the diploid species, namely $B$. fistulosa, B. jacquemontii, B. oxyodonta and B. wightiana, chromosomes 1 and 2 are remarkably larger in size than the rest of the chromosomes such that

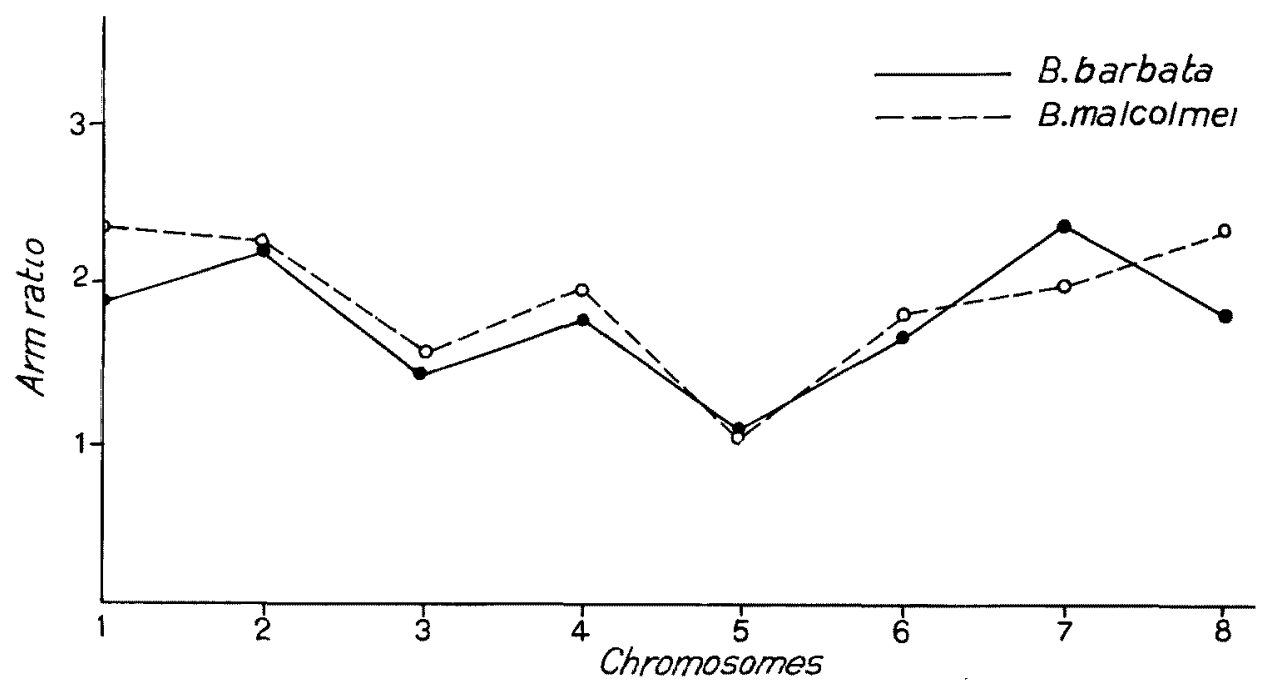

Fig. 11. Arm ratios in two $\mathrm{x}=8$ species of Blumea.

their karyotypes can be considered as bimodal. In the $x=9$ tetraploid species, B. lacera var. glandulosa also such a bimodality is recognizable. Here, four pairs of chromosomes are clearly larger than the rest. According to Lewitzky (1931), bimodality arises as a result of periodical unequal translocations between nonhomologous chromosomes such that the donors gradually become smaller and the recipients correspondingly larger. In such cases the number of short chromosomes will be approximately equal to that of the larger ones (Stebbins 1971). But, in the present species with bimodal karyotypes, the short chromosomes greatly outnumber the longer ones (7:2), and hence it appears that unequal translocations alone cannot account for the higher incidence of short chromosomes. Darlington's (1963) postulation regarding the origin of bimodal karyotypes is relevant here. According to him, bimodality originates from symmetrical karyotypes of species of polyloid origin which have many gene loci in duplicate so that loss of segments of chromosomes may be tolerated. In this connection, our earlier suggestion of polyploid origin of the present-day diploid species of Blumea from ancestral taxa with $n=5$ is interesting (Mathew and Mathew 1975), and it is possible that in the origin of bimodality in species of Blumea, loss of chromosome segments also must have been strongly operative.

Of the seven $x=9$ species reported here, two species which do not show bimodality are the ones which show least asymmetry of the karyotypes, namely $B$. virens (2A) and B. membranacea var. gardneri (1A). It may be noted here that 
among the $x=9$ species, those with bimodal karyotypes are found to show more advanced morphological features than those which possessed graded karyotypes. In the latter group, there was larger plant size, corymbosely branched open flowering stems and long peduncled heads. This situation appears to indicate that in the $\mathrm{x}=9$ group of species of Blumea, morphological advancement has accompanied karyotype specialization.

\section{Summary}

Karyomorphology of nine species of Blumea has been presented such as $B$. barbata $(2 \mathrm{n}=16)$, B. fistulosa $(2 \mathrm{n}=18), B$. jacquemontii $(2 \mathrm{n}=18)$, B. lacera var. glandulosa $(2 \mathrm{n}=36), B$. malcolmei $(2 \mathrm{n}=16)$, B. membranacea var. gardneri $(2 \mathrm{n}=18)$, B. oxyodonta $(2 \mathrm{n}=18)$, B. virens $(2 \mathrm{n}=18)$ and $B$. wightiana $(2 \mathrm{n}=18)$.

Karyotypes of both the $\mathrm{x}=9$ and $\mathrm{x}=8$ species are moderately asymmetrical (2A and $2 B$ ). In finer details, the karyotypes of $x=9$ species are seen to be more specialized. Five $x=9$ species showed bimodal karyotypes and in all of them the short chromosomes greatly outnumbered the long ones.

Species possessing bimodal karyotypes showed more advanced morphological characters, and this appears to indicate an association between karyotype specialization and morphological advancement of plants in the genus.

\section{Acknowledgement}

The authors are indebted to Dr. C. A. Ninan, Professor of Genetics and Plant Breeding and Head of the Department of Botany, University of Kerala for valuable suggestions and encouragement. One of us (AM) is grateful to the CSIR, Government of India for the award of a Senior Research Fellowship.

\section{References}

Chennaveeraiah, M. S. and Patil, R. M. 1972. Apomixis in Blumea. Phytomorphology 21: $71-76$.

Darlington, C. D. 1963. Chromosome Botany and Origins of Cultivated Plants. George Allen and Unwin, London.

Gupta, P. K. 1969. Cytological investigations on some Indian Compositae. Cytologia 34:429438.

Levan, A., Fredga, K. and Sandberg, A. A. 1964. Nomenclature for centromeric position on chromosomes. Hereditas 52: 201-220.

Levitzky, G. A. 1931. The "Karyotype" in systematics. Bull. of Appl. Bot. Genet. and Plant Breeding 27: 187-240.

Henderson, S. A. and Lu, B. C. 1968. The use of haematoxylin for the squash preparation of chromosomes. Stain Technol. 43:233-236.

Mathew, A. and Mathew, P. M. 1975. Studies on South Indian compositae. Cytology of the genus Blumea DC. Cytologia 40: 365-370.

- and - 1976. Studies on South Indian Compositae II. Cytology of the genus Vernonia Schreb. Cytologia 41: 401-406.

Mehra, P. N., Gill, B. S., Mehta, J. K., and Sidhu, S. S. 1965. Cytological investigations on the Indian Compositae I. North Indian taxa. Caryologia 18: 35-68. 
Miyagi, C. 1971. Chromosome numbers in spermatocytes from Okinawa Islands. Biol. Mag. Okinawa 8: 14-23.

Stebbins, G. L. 1958. Longivity, habitat and release of genetic variability in higher plants. Cold Spring Harb. Symp. Quart. Biol. 23: 365-378.

- 1971. Chromosomal Evolution in Higher Plants. Addison-Wesley Publishing Co. 